\title{
Epigenetic regulation of development by histone lysine methylation
}

\author{
S Dambacher ${ }^{1}, \mathrm{M} \mathrm{Hahn}^{1}$ and G Schotta \\ Munich Center for Integrated Protein Science (CiPS $\left.{ }^{M}\right)$ and Adolf-Butenandt-Institute, Ludwig-Maximilians-University, Munich, \\ Germany
}

\begin{abstract}
Epigenetic mechanisms contribute to the establishment and maintenance of cell-type-specific gene expression patterns. In this review, we focus on the functions of histone lysine methylation in the context of epigenetic gene regulation during developmental transitions. Over the past few years, analysis of histone lysine methylation in active and repressive nuclear compartments and, more recently, genome-wide profiling of histone lysine methylation in different cell types have revealed correlations between particular modifications and the transcriptional status of genes. Identification of histone methyltransferases
\end{abstract}

(HMTases) and specific binding factors for most methylated lysine positions has provided a novel insight into the mechanisms of epigenetic gene regulation. In addition, analyses of HMTase knockout mice show that histone lysine methylation has important functions for normal development. In this study, we review mechanisms of gene activation and repression by histone lysine methylation and discuss them in the context of the developmental roles of HMTases.

Heredity (2010) 105, 24-37; doi:10.1038/hdy.2010.49; published online 5 May 2010

Keywords: epigenetics; histone lysine methylation; heterochromatin; mouse development

\section{Introduction}

Development is accomplished by spatial and temporal regulation of gene expression patterns. The identity of each cell type is maintained and passed on to daughter cells by mechanisms that do not alter the DNA sequence and are therefore regarded as epigenetic. A major mechanism to establish cell-type-specific expression patterns is transcriptional regulation. The physiological template for transcription is chromatin, and therefore epigenetic mechanisms are thought to modulate its structure, making DNA more or less accessible to the transcriptional machinery. Today, we know of five major mechanisms that alter chromatin architecture: DNA methylation, post-translational histone modifications, use of histone variants, chromatin remodeling and incorporation of non-coding RNA into chromatin. These mechanisms are generally considered 'epigenetic', although we still lack good understanding as to the stability of these modifications through mitosis or even through the germ line.

In this review, we will focus on the functions of histone lysine methylation during development. In the first part, we will discuss how histone lysine methylation facilitates gene activation or repression of genomic regions. In the context of these activities, we will then discuss the developmental roles of selected histone methyltransferases (HMTases).

Correspondence: Professor G Schotta, Adolf-Butenandt-Institute, LudwigMaximilians-University, Schillerstrasse 44, Munich 80336, Germany. E-mail: gunnar.schotta@med.uni-muenchen.de

${ }^{1}$ These authors contributed equally to this work.

Received 8 November 2009; revised 16 March 2010; accepted 18 March 2010; published online 5 May 2010

\section{Activation and repression are facilitated by histone lysine methylation}

Major methylation sites on histones $\mathrm{H} 3$ and $\mathrm{H} 4$ are located in the tail (H3K4, H3K9, H3K27, H3K36 and H4K20) and the nucleosome core region (H3K79). Although histone methylation was discovered nearly four decades ago (Allfrey et al., 1964), a correlation between this modification and gene regulation has only recently been established. Strahl et al. (1999) showed that H3K4 methylation was highly enriched in macronuclei of Tetrahymena, suggesting a role for this modification in transcriptional activation. A year later, H3K9 methylation was implicated in gene repression when a homolog of the heterochromatin-associated Drosophila Su(var)3-9, Suv39h1, was shown to have H3K9-specific methyltransferase activity (Rea et al., 2000).

Lysine residues can be mono (me1), di (me2) or trimethylated (me3), and binding of specific proteins, which recognize methylated lysine positions, can result in different biological outcomes. The development of highly specific antibodies that discriminate not only between lysine positions, but also between methylation states, allowed the large-scale mapping of individual histone lysine methylation marks by chromatin immunoprecipitation on tiling arrays or chromatin immunoprecipitation followed by sequencing (reviewed in Lee and Mahadevan, 2009). In combination with gene expression data, correlations between histone modifications and gene activity have now been established. A number of modifications show some correlation with the transcriptional status of genes; however, only a very few marks are consistently found on active or inactive genes. The hallmark of transcriptionally active genes is H3K4me3 in the promoter region and H3K36me3 
across the gene body (Figure 1). H3K27me3 seems central for gene repression and covers the gene body and flanking regions (Figure 1). The average profile of repressed genes shows enrichment of H3K9me3 and H4K20me3 at a much lower level when compared with $\mathrm{H} 3 \mathrm{~K} 27 \mathrm{me}$, suggesting that these marks are less important for gene silencing (Figure 1). In the next sections, we will discuss the current view of how active and repressive modifications are established and how they contribute to the transcriptional regulation of genes.

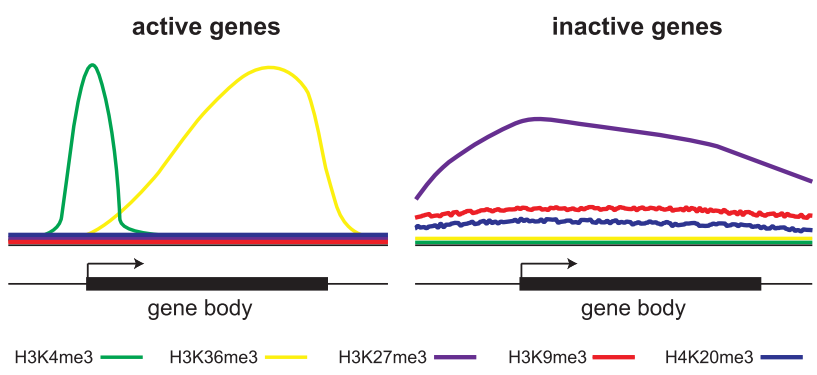

Figure 1 Profiles of histone lysine methylation at active and inactive mammalian genes. At active genes, $\mathrm{H} 3 \mathrm{~K} 4 \mathrm{me} 3$ is highly enriched at the promoter region, whereas H3K36me3 associates with the gene body. At repressed genes, H3K27me3 covers the gene body and flanking regions. H3K9me3 and H4K20me3 are also enriched at inactive genes, although at a lower level (adapted from Barski et al., 2007, Pauler et al., 2009 and Cui et al., 2009).

\section{Histone lysine methylation marks in the context of transcriptional activation}

The amount of transcript per cell is controlled through multiple mechanisms. If we only consider the rate of transcription, at least two major steps regulate how much primary transcript is produced. In the first step, RNA polymerase II (Pol II) is recruited to the promoter region and forms a pre-initiation complex (PIC). However, this is not sufficient for transcription, as RNA Pol II can be stalled at promoters and a second trigger is therefore required for elongation (Core and Lis, 2008). Histone lysine methylation is an important regulatory element for both determining processes. It exerts an effect by recruiting specific binding factors, providing stable interaction platforms for the basic transcriptional machinery and for activities that regulate the ordered dis- and reassembly of chromatin during elongation.

\section{Transcription initiation}

Active genes carry high levels of H3K4me3 in the promoter region. This modification is a binding platform for a number of proteins (Table 1), including chromatin remodelers, which help to open the chromatin structure around the promoter and facilitate the binding of the basic transcriptional machinery. BPTF (bromodomain PHD finger transcription factor), a subunit of the NURF (nucleosome remodeling factor) remodeling complex, and Chd1, another chromatin

Table 1 Mammalian histone methylation binders and their possible functions

\begin{tabular}{|c|c|c|c|}
\hline Histone modification & Reader & Function & Reference \\
\hline \multicolumn{4}{|l|}{ H3K4 } \\
\hline me2, me3 & Chd1 & Chromatin remodeling & Flanagan et al. (2005) \\
\hline me3 & Bptf & Chromatin remodeling & Wysocka et al. (2006) \\
\hline me3 & Taf3 & TFIID stabilization & Vermeulen et al. (2007) \\
\hline me3 & Ing1 & Recruitment of HATs & Taverna et al. (2006) \\
\hline me3 & Ing2 & Recruitment of HDACs & Shi et al. (2006) \\
\hline me3 & Ing4 & Recruitment of HATs & Hung et al. (2009) \\
\hline me3 & Ing5 & Recruitment of HATs & Champagne et al. (2008) \\
\hline me3 & Jmjd2a & H3K9 demethylation & Lee et al. (2008b) \\
\hline me3 & Chd7 & Chromatin remodeling & Takada et al. (2007) \\
\hline me3 & Rag2 & VDJ recombination & Matthews et al. (2007) \\
\hline \multicolumn{4}{|l|}{ H3К9 } \\
\hline me1, me2 & G9a-GLP & Transcriptional silencing & Collins et al. (2008) \\
\hline me3 & HP1 & Heterochromatin & Lachner et al. (2001) \\
\hline me3 & Tip60 & DNA repair & Sun et al. (2009) \\
\hline me3 & Chd7 & Chromatin remodeling & Takada et al. (2007) \\
\hline me3 & Cdyl2 & Heterochromatin & Fischle et al. (2008) \\
\hline \multicolumn{4}{|l|}{ H3K27 } \\
\hline me3 & $\mathrm{Cbx} 2,4,7$ & Polycomb-mediated gene silencing & Bernstein et al. (2006b) \\
\hline me3 & Eed & Polycomb-mediated gene silencing & Margueron et al. (2009) \\
\hline \multicolumn{4}{|l|}{ H3К36 } \\
\hline me3 & Mrg15 & Recruitment of HDACs & Zhang et al. (2006) \\
\hline \multicolumn{4}{|l|}{ H3К79 } \\
\hline me1, me2 & $53 b p 1$ & DNA damage repair & Huyen et al. (2004) \\
\hline \multicolumn{4}{|l|}{ H4K2O } \\
\hline me1, me2 & L3mbtl1 & Chromatin compaction & Trojer et al. (2007) \\
\hline me2 & 53bp1 & DNA damage repair & Botuyan et al. (2006) \\
\hline me3 & Jmjd2a & H3K9 demethylation & Lee et al. (2008b) \\
\hline
\end{tabular}

Abbreviations: HAT, histone acetyltransferase; HDAC, histone deacetylase. 

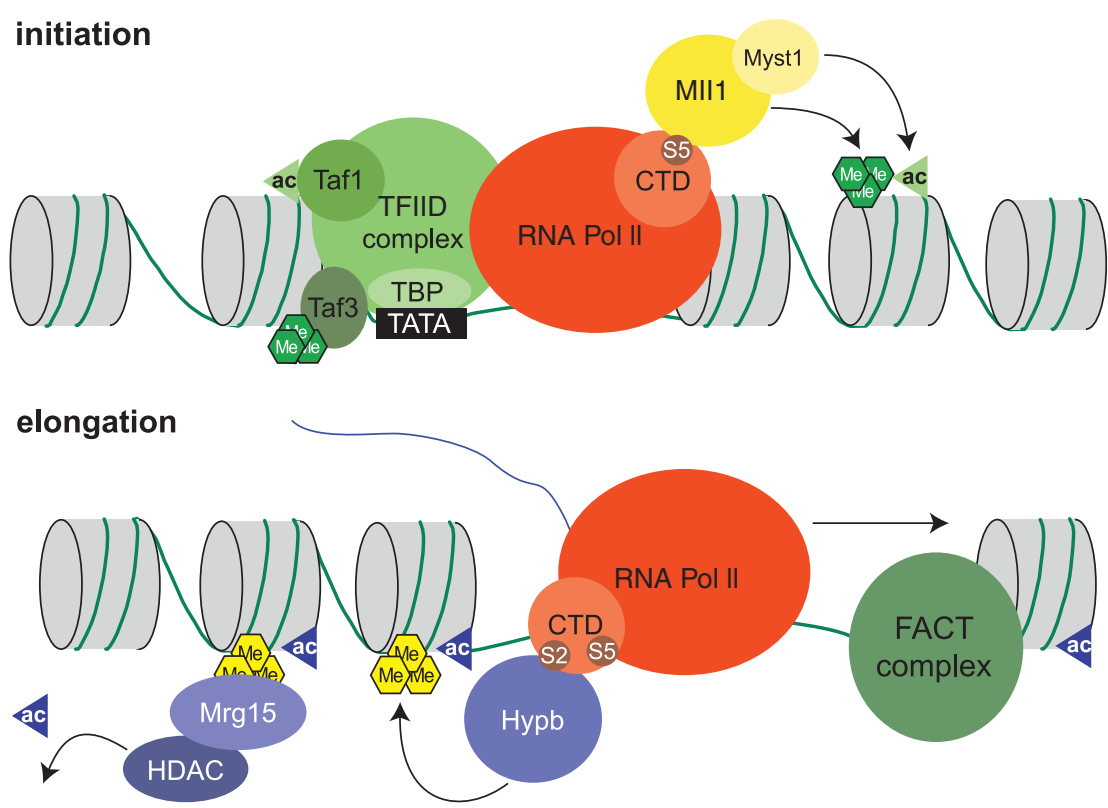

Figure 2 Histone lysine methylation marks in the context of transcriptional activation. During initiation, TFIID is targeted to the promoter region through multiple interactions between its subunits and chromatin modifications (see text for details). RNA Pol II is positioned near the transcriptional start site and phosphorylated at Ser 5 of its CTD. The Mll1 complex binds to S5-P CTD and introduces H3K4me3 as well as acetylation of H4. Phosphorylation at Ser 2 of the CTD starts the elongation phase. The FACT complex disrupts nucleosomes in front of elongating RNA Pol II. Hypb binds to S2-P CTD and induces H3K36me3, which is recognized by Mrg15 leading to deacetylation of histones due to recruitment of histone deacetylases (HDACs).

remodeler, can bind H3K4me3 (Flanagan et al., 2005; Wysocka et al., 2006). Although these data implicate chromatin remodeling in promoter activation, we still lack detailed mechanistic insight.

Other binding proteins of $\mathrm{H} 3 \mathrm{~K} 4 \mathrm{me} 3$ seem to be important for recognition of the promoter region. The TFIID complex is involved in the first step of PIC formation, and binds the promoter through multiple interactions between its subunits, DNA and histone modifications (Figure 2). The TATA box binding protein (TBP) subunit, for example, and other associated proteins recognize the promoter DNA sequence. This can be either the TATA box itself or associated sequences, such as initiator and downstream promoter elements. The chromatin state is recognized by another TFIID subunit, the double bromodomain protein Taf1, which can bind acetylated lysines at positions H3K9 and H3K14 (Jacobson et al., 2000). More recently, yet another TFIID component, the PHD domain protein Taf3, was shown to bind H3K4me3 (Vermeulen et al., 2007). These data suggest that multiple interactions are necessary for stable recruitment of the PIC. The next step in the initiation cascade is binding of RNA Pol II to the promoter region and phosphorylation of Ser 5 in its carboxy-terminal domain (CTD) repeats by Cdk7. RNA Pol II is then able to generate short transcripts; however, interaction with DSIF (DRB sensitivity-inducing factor) and NELF (negative elongation factor) can inhibit elongation (reviewed in Fuda et al., 2009).

Is $\mathrm{H} 3 \mathrm{~K} 4 \mathrm{me} 3$ at the promoter a cause or a consequence of transcriptional activity? Currently, there is no general answer to this question and every promoter might behave somewhat differently. In vitro data suggest that this modification has no direct effect on transcription (Pavri et al., 2006; Kim and Buratowski, 2009); however, the reduced complexity of in vitro systems might mask an effect that is relevant in vivo. It is noteworthy that some inducible promoters carry H3K4me3 even before RNA Pol II is detectable, indicating that H3K4me3 can be established in the absence of active transcription (Edmunds et al., 2008). Several enzymes can induce H3K4me3 (Table 2), and elucidating how they are recruited and how their HMTase activity is regulated will be important in furthering our understanding of this modification. There is evidence that the CTD exerts an effect as a recruiting platform for different chromatinmodifying activities. For example, Mll1, a major H3K4specific methyltransferase, interacts with the Ser 5 phosphorylated CTD and establishes or reinforces H3K4me3 around the promoter region (Milne et al., 2005).

\section{Transcription elongation}

Binding to H3K4me3 might stabilize the PIC at the promoter and could therefore increase the probability of initiating transcription. The other mechanism to control the transcription rate is elongation (Figure 2). RNA Pol II can be stalled at promoters by interaction with NELF and DSIF. Elongation is then induced by phosphorylation of DSIF and RNA Pol II CTD at Ser 2 by the P-TEFb (positive transcription elongation factor $\mathrm{b}$ ) complex (reviewed in Fuda et al., 2009). For RNA Pol II to traverse nucleosomal templates, the chromatin structure needs to be relaxed. This is facilitated through eviction of H2A/ $\mathrm{H} 2 \mathrm{~B}$ dimers by the FACT complex (Belotserkovskaya and Reinberg, 2004). After passage of RNA Pol II, the FACT complex could also be involved in the reassembly of a proper chromatin structure (Jamai et al., 2009).

Several histone modifications are established when RNA Pol II travels through the gene body. The Ser 2 phosphorylated CTD associates with H3K36-specific 
Table 2 Mammalian HMTases, their activities and knockout phenotypes

\begin{tabular}{|c|c|c|c|c|}
\hline HMTase & Activity & Reference & Viability & Phenotype \\
\hline Ash11 & H3K4 & Gregory et al. (2007) & & \\
\hline Dot11 & H3К79 & Feng et al. (2002) & E9.5-10.5 & $\begin{array}{l}\text { Growth retardation, angiogenesis defects in the yolk sac, } \\
\text { and cardiac dilation, loss of all H3K79 methylation (Jones et al., 2008) }\end{array}$ \\
\hline Ezh1 & H3К27 & $\begin{array}{l}\text { Margueron et al. (2008); } \\
\text { Shen et al. (2008) }\end{array}$ & & \\
\hline Ezh2 & H3К27 & Cao et al. (2002) & E8.5 & Arrested development, gastrulation failure (O'Carroll et al. 2001) \\
\hline G9a & $\mathrm{H} 3 \mathrm{~K} 9 \mathrm{me} 1 / 2$ & Tachibana et al. (2002) & E9.5-12.5 & Growth retardation, reduction in $\mathrm{H} 3 \mathrm{~K} 9$ me1, me2 (Tachibana et al., 2002) \\
\hline GLP & H3K9me1/2 & Tachibana et al. (2008) & E9.5-12.5 & Growth retardation, reduction in H3K9 me1, me2 (Tachibana et al., 2005) \\
\hline Mll1 & H3K4 & Milne et al. (2002) & E12.5-16.5 & $\begin{array}{l}\text { Patterning defects (Yu et al., 1995; Yagi et al., 1998) } \triangle \text { SET mutant viable, } \\
\text { skeletal defects (Terranova et al., 2006) }\end{array}$ \\
\hline Mll2 & H3К 4 & Goo et al. (2003) & E11.5 & Growth retardation, increased apoptosis (Glaser et al., 2006) \\
\hline Mll3 & H3К 4 & Lee et al. (2006) & Viable & $\begin{array}{l}\text { Partial embryonic lethality, growth retardation, female infertility } \\
\text { (Lee et al., 2006) }\end{array}$ \\
\hline Mll4 & H3K4 & Lee et al. (2006) & & \\
\hline Mll5 & $\mathrm{H} 3 \mathrm{~K} 4$ & Fujiki et al. (2009) & Viable & $\begin{array}{l}\text { Hematopoietic defects, male infertility (Heuser et al., 2009; Liu et al., 2009; } \\
\text { Madan et al., 2009) }\end{array}$ \\
\hline Nsd1 & H3К36 & Rayasam et al. (2003) & E9.5 & Growth retardation, apoptosis (Rayasam et al., 2003) \\
\hline Prdm1 & & & E10.5 & Patterning defects (Ohinata et al., 2005) \\
\hline Prdm2 & H3K9me2 & Kim et al. (2003) & Viable & Tumorigenesis (Steele-Perkins et al., 2001) \\
\hline Prdm3 & & & E13.5-16.5 & Broad developmental defects (Hoyt et al., 1997) \\
\hline
\end{tabular}

Prdm5

Prdm6

Prdm8

Prdm9

Impaired sex body formation, infertility (Hayashi et al., 2005)

Prdm11

$\operatorname{Prdm} 12$

$\operatorname{Prdm} 13$

Prdm14

Prdm15

Prdm16

PrSet7

H4K20me1

Nishioka et al. (2002)

Viable

Infertility, devoid of germ cells (Yamaji et al., 2008)

Setd1a

H3K4

Setd1b H3K4

Setd2 H3K36

Wysocka et al. (2003)

Eight-cell

G2/M arrest, chromosome condensation defects (Oda et al., 2009)

Setd3

Setd4

Setd5

Setd6

Lee et al. (2007)

Sun et al. (2005)

Setd7

Setdb1

Setdb2

Setmar

Smyd1

H3K4me1/2 Wang et al. (2001)

H3K9 Yang et al. (2002)

H3K36 Lee et al. (2005)

H3K4me1/2/3 Tan et al. (2006)

Smyd2

Smyd3

Smyd4

Smyd5

Suv39h1

H3K36 Brown et al. (2006)

H3K4me2/3 Hamamoto et al. (2004)

Suv39h2 H3K9me2/3 Rea et al. (2000)

Suv4-20h1 H4K20me2/3 Schotta et al. (2004)

Suv4-20h2 H4K20me2/3 Schotta et al. (2004)

Whsc1 H3K36 Nimura et al. (2009) 
modifications across the gene body can even affect processing of the RNA transcript, such as selection of polyadenylation sites or even splicing (KolasinskaZwierz et al., 2009; Spies et al., 2009). These surprising connections between chromatin structure and RNA processing will reveal novel mechanisms for the regulation of cell-type-specific transcription profiles.

\section{Repressive histone lysine methylation marks}

Transcriptional repression is important for various aspects of development. On one hand, cell-type-specific expression patterns are regulated by silencing of lineageinappropriate genes during differentiation, and on the other hand, large regions of mammalian genomes consist of non-coding DNA sequences such as satellite repeats, telomeric repeats, mobile elements and interspersed repeats, which need to be under tight transcriptional control to prevent genomic instability. Genome-wide mapping studies of histone modifications consider only the nonrepetitive part of the genome and from these data it seems that $\mathrm{H} 3 \mathrm{~K} 27 \mathrm{me} 3$ is a major modification that correlates with the transcriptional repression of genes (Figure 1). In contrast, repetitive genomic regions are marked by $\mathrm{H} 3 \mathrm{~K} 9 \mathrm{me} 3$ and $\mathrm{H} 4 \mathrm{~K} 20 \mathrm{me} 3$. In the following sections, we will discuss the establishment and potential functions of repressive histone modifications at both highly repetitive genomic regions and at individual genes.

\section{Silencing of repetitive genomic regions}

\section{Pericentric heterochromatin}

The largest family of repetitive regions consists of major satellite repeats that are the main constituents of pericentric heterochromatin. Major satellite repeats have a distinct $\mathrm{H} 3 \mathrm{~K} 9 \mathrm{me} 3+\mathrm{H} 4 \mathrm{~K} 20 \mathrm{me} 3$ chromatin signature, which is found in almost all cell types and developmental stages, suggesting that these modifications have a general function in heterochromatin. H3K9me3 is established by Suv39h1 and Suv39h2 enzymes (Rea et al., 2000). Two other HMTases, Suv4-20h1 and Suv4-20h2, establish H4K20me3 (Schotta et al., 2004). Recent data suggest a novel modification, H3K64me3 that has a role in pericentric heterochromatin formation during the early stages of mouse development (Daujat et al., 2009); however, the responsible methyltransferase has not been identified as yet.

The combinatorial pattern of histone lysine methylation at heterochromatin is established in a sequential pathway (Figure 3). In Schizosaccharomyces pombe, doublestranded RNA from centromeric repeats is processed by components of the RNA interference machinery. This leads to recruitment of Clr4, the $S$. pombe homolog of Suv39h, to establish H3K9 methylation at heterochromatin (Grewal and Jia, 2007). In mammals, it is still unclear whether a similar link between processing of doublestranded RNA and recruitment of Suv39h exists. H3K9me3 is likely to be established in a highly coordinated manner during replication of pericentric heterochromatin. Recent data suggest that, in a first step, Setdb1 (SET domain bifurcated 1), in complex with heterochromatin protein $1 \alpha$ (HP1 $\alpha)$ and CAF1 (chromatin assembly factor 1), induces H3K9me1 on

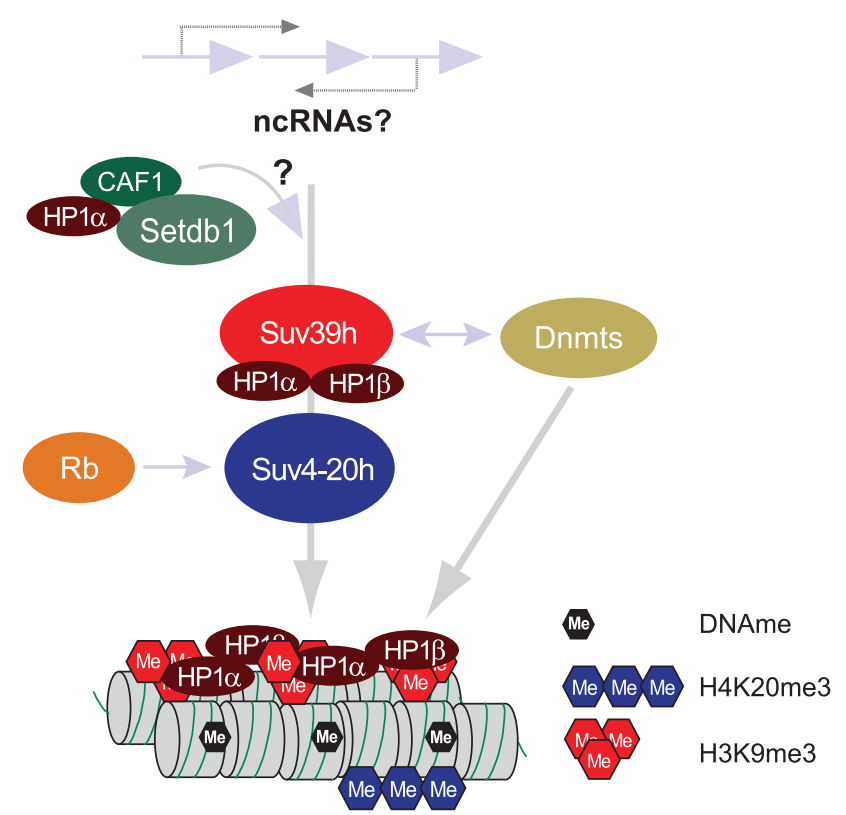

Figure 3 Repressive histone lysine methylation marks at heterochromatin are established in a sequential pathway. The Setdb1/ CAF1/HP1 $\alpha$ complex presumably induces H3K9me1, which is converted to H3K9me3 by Suv39h enzymes. H3K9me3 exerts an effect as a binding platform for HP1 proteins, which in turn recruit Suv4-20h enzymes to induce H4K20me3. Establishment of these modifications is also regulated through interactions with other proteins, for example, members of the retinoblastoma $(\mathrm{Rb})$ family. There is also evidence for interaction of DNA methyltransferases with Suv39h enzymes; however, this interplay needs further characterization.

non-nucleosomal histone H3 (Loyola et al., 2009). Subsequently, Suv39h enzymes, which prefer H3K9me1 as substrate, induce H3K9me3, probably even before the H3 molecule is deposited into a nucleosomal context (Rea et al., 2000). Nucleosomal H3K9me3 exerts an effect as a binding platform for HP1 proteins, which in turn recruit Suv4-20h enzymes to establish H4K20me3 (Schotta et al., 2004). The direct interaction of Suv4-20h enzymes with HP1 is necessary to induce H4K20me3; however, interactions with other proteins, for example, members of the retinoblastoma family, can contribute to the establishment of this modification (Gonzalo et al., 2005).

What are the functions of histone lysine methylation marks at pericentric heterochromatin? Although considered highly compact and transcriptionally silent, there is increasing evidence for controlled transcription across pericentric heterochromatin (Eymery et al., 2009). Promoter elements are still unknown, and owing to the repetitive nature of these transcripts they have yet to be characterized. However, it is clear that transcription from major satellite repeats is tightly controlled, occurring only during distinct cell cycle stages. Suv39h double-null mutants show enhanced amounts of major satellite transcripts (Martens et al., 2005), indicating that H3K9me3 has an important role in controlling the transcript levels from these repeat regions. How this control is accomplished, whether $\mathrm{H} 3 \mathrm{~K} 9 \mathrm{me} 3$ or its binding factors hinder access to RNA Pol II or whether RNA processing or RNA stability are regulated by this modification are some challenging questions in this field. 


\section{Telomeric silencing}

The chromatin structure at telomeres is very similar to that of pericentric heterochromatin. Telomeric repeats are enriched for Suv39h-mediated $\mathrm{H} 3 \mathrm{~K} 9 \mathrm{me}$. As in heterochromatin, $\mathrm{H} 3 \mathrm{~K} 9 \mathrm{me} 3$ exerts an effect as a binding platform for HP1 proteins that recruit Suv4-20h enzymes to induce H4K20me3 (Benetti et al., 2007). At telomeres, this sequential pathway is affected by the H3K79-specific HMTase Dot1l. It is noteworthy that Dot1l-mutant cells lose all H3K79 methylation and that at telomeres even H4K20me3 is lost (Jones et al., 2008). Currently, it is not known whether Dot1l or H3K79 methylation affects the activity or recruitment of Suv4-20h enzymes.

Transcripts from telomeric repeats (TelRNAs) are generated by RNA Pol II and are normally polyadenylated (Schoeftner and Blasco, 2008). Interestingly, TelRNAs seem to be a structural constituent of telomeric chromatin. They can block telomerase activity, and therefore a possible function of these transcripts is the regulation of telomere length. In the absence of Suv39h or Suv4-20h enzymes, TelRNAs are upregulated, suggesting that $\mathrm{H} 3 \mathrm{~K} 9 \mathrm{me} 3$ and $\mathrm{H} 4 \mathrm{~K} 20 \mathrm{me} 3$ function as repressive modifications at telomeres (Schoeftner and Blasco, 2008).

\section{Gene silencing}

Gene activation is largely correlated with the establishment of H3K4me3. In contrast, different modifications exist to mediate gene silencing. Average chromatin immunoprecipitation profiles across silenced genes suggest $\mathrm{H} 3 \mathrm{~K} 27 \mathrm{me} 3$ as a prominent modification for gene repression (Figure 1); however, there is also evidence that H3K9me3 and H4K20me3 are associated with repressed genes. Interestingly, different studies have found that there is a large proportion of silent genes that do not carry any of the tested epigenetic modifications. It is possible that these genes are passively repressed and that their silent state is just due to the lack of activating factors. However, we still lack knowledge about many histone modifications and their mechanisms of action, and it could well be that novel mechanisms for transcriptional silencing will be discovered in the near future. In the next sections, we will discuss how gene repression is established by the classic repressive histone modifications, H3K27me3 and H3K9me3.

Polycomb silencing by H3K27 methylation H3K27 methylation only exists in multicellular organisms and has probably evolved as a system to facilitate cell-type differentiation. Surprisingly, in embryonic stem (ES) cells, H3K27me3 can coexist in the same region with H3K4me3 (Bernstein et al., 2006a). Genes that carry this 'bivalent' modification are mainly developmental regulators. Although bivalent genes are repressed, they carry engaged but stalled RNA Pol II. In differentiated cells, bivalent chromatin domains are reduced and genes that are active or repressed are characterized by H3K4me3 or H3K27me3, respectively (Mikkelsen et al., 2007). It is not clear how bivalent marks are reduced to a univalent form during differentiation. One possibility is that during replication the bivalent modification cannot be 'copied' and either H3K4me3 or H3K27me3 is established on the newly replicated chromatin. Another postulation is that chromatin modifications at a particular gene reflect an equilibrium between antagonizing activities of transcriptional activators and repressors. Unequal cell division during differentiation of pluripotent progenitor cells might shift this balance to either side. Bivalent chromatin might also represent a transient state during differentiation. In ES cells, the major pluripotency genes Nanog, Sox2 and Oct4, are highly expressed and marked with H3K4me3. During differentiation, these genes transiently acquire a bivalent state before they become silenced with H3K27me3 (Pan et al., 2007).

H3K27 methylation is mediated by the two highly related enzymes, Ezh1 (enhancer of zeste homolog 1) and Ezh2 (Table 2). Ezh enzymes form the so-called polycomb repressive complex 2 (PRC2) with Eed, Suz12 and $\mathrm{RbAp} 46 / 48$ proteins (Margueron et al., 2008). It is noteworthy that ES cells in which PRC2 complex members such as Eed or Suz12, are disrupted, largely lose H3K27me2 and H3K27me3 (Schoeftner et al., 2006; Chamberlain et al., 2008), suggesting that these proteins exert an effect as cofactors to fully stimulate enzymatic activity of Ezh enzymes.

H3K27me3 recruits the PRC1 complex (Ring1a/b, Bmi1, Ph, Cbx2) through interaction with the Cbx2 chromo domain (Figure 4). Other Cbx2 homologs bind H3K27me3 and can be part of PRC1-related complexes (Bernstein et al., 2006b). For the recruitment of PRC1, binding to H3K27me3 is essential but probably not sufficient. This became clear through genome-wide mapping of PRC1 and PRC2 complexes (Ku et al., 2008). Only a subset of regions with high levels of H3K27me3 also shows enrichment for PRC1 complex members. However, removal of H3K27me3 leads to complete loss of PRC1 from its targets (Cao et al., 2002; Leeb et al., 2010). An important function of PRC1 is the establishment of a second histone modification, $\mathrm{H} 2 \mathrm{~A}$ ubiquitylation on
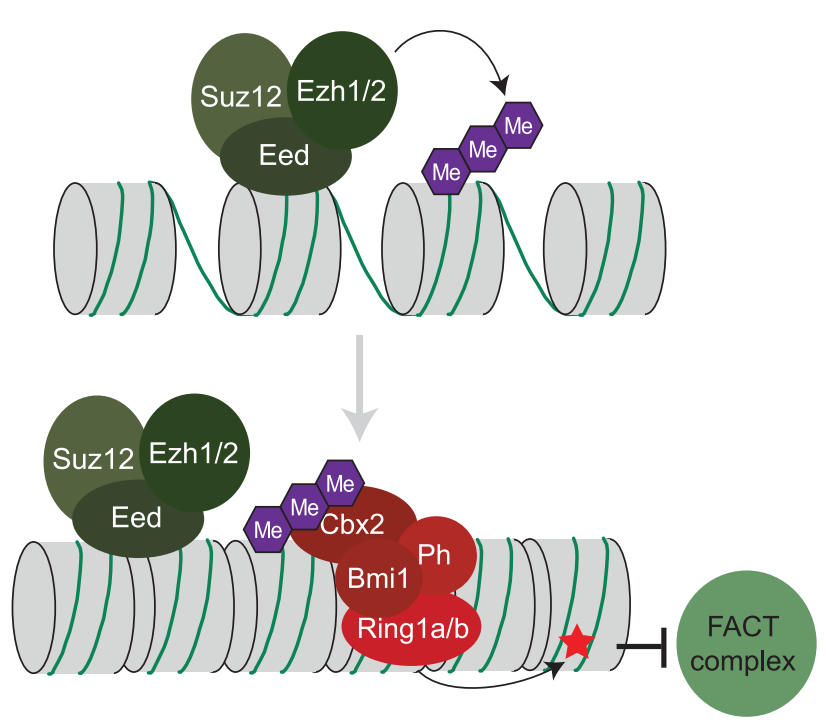

Figure 4 Polycomb-mediated gene silencing. Ezh1/2 enzymes, Suz12 and Eed, form the PRC2 core complex and induce H3K27me3. This modification is recognized by the chromo domain of mammalian Pc homologs, for example $\mathrm{Cbx2}$, which is a subunit of the PRC1 complex. Ring1a/b, another PRC1 subunit, establishes H2AK119ub, which inhibits nucleosome disassembly by the FACT complex. 
lysine 119 (H2AK119ub) by the Ring1a/b subunit (Wang et al., 2004).

The mechanism for transcriptional repression by the polycomb system (Figure 4) is still under debate. In vitro data suggest that PRC1 and PRC2 components can compact recombinant nucleosomes and block transcriptional elongation on chromatinized templates (Margueron et al., 2008); however, these mechanisms are very difficult to verify in vivo. A more compact chromatin structure might as well prevent promoter recognition by the PIC. Another intriguing finding is that H2AK119ub prevents recruitment of FACT (Zhou et al., 2008), which could impair transcriptional elongation. These and maybe other epigenetic mechanisms, such as binding of non-coding RNAs (Rinn et al., 2007) and DNA methylation (Vire et al., 2006), work together in the establishment of polycomb-mediated gene silencing. However, future studies are needed to dissect the interplay between these mechanisms.

\section{Imprinting}

Genomic imprinting is a well-characterized system that mainly uses epigenetic mechanisms to induce stable gene repression. Imprinted genes are only expressed from one allele; the other allele is permanently silenced using a heterochromatin-like mechanism. Silencing is established by repressive histone modifications and DNA methylation over so-called imprinting control regions (ICRs), which inhibit promoter activation or can block enhancer action.

Imprinted loci show allelic differences in epigenetic patterns. The ICR of the silenced allele carries heterochromatin-like modifications (H3K9me3 + H4K20me3), whereas the active allele is marked with $\mathrm{H} 3 \mathrm{~K} 4 \mathrm{me} 3$ (Fournier et al., 2002; Regha et al., 2007; Pannetier et al., 2008). Not all imprinted genes are regulated in the same way, and in different developmental stages distinct mechanisms might be used to establish gene silencing. A surprising example is the discovery that imprinting in extraembryonic cells of the placenta uses a repression mechanism that mainly involves H3K27me3 (Lewis et al., 2004; Umlauf et al., 2004).

Histone methylation at ICRs reflects the heterochromatic H3K9me3 + H4K20me3 modification pattern; however, there are differences in the enzymatic systems and probably also in the recruitment mechanisms. In particular, the nature of the H3K9me3 HMTase in the context of imprinting is still somewhat unclear as Suv39h enzymes do not affect histone methylation at ICRs. Recently, another H3K9-specific HMTase, Setdb1, was found to associate with a particular imprinted region; however, no mechanistic studies have been performed to confirm a function of this enzyme in imprinting (Regha et al., 2007). As in pericentric heterochromatin, $\mathrm{H} 3 \mathrm{~K} 9 \mathrm{me} 3$ might serve as a binding platform for HP1 proteins, which can then recruit Suv4-20h enzymes to induce H4K20me3 at ICRs. In somatic cells, silencing of imprinted genes strongly depends on DNA methylation. We still do not know to what extent histone modifications contribute to silencing in this context. It could well be possible that histone methylation at ICRs functions downstream of DNA methylation (Henckel et al., 2009). Histone methylation could also represent an additional layer of complexity to ensure stability of the repressed state.

\section{Gene silencing by H3K9 methylation}

Average histone modification profiles across genes have revealed a weak correlation between $\mathrm{H} 3 \mathrm{~K} 9 \mathrm{me} 3$ and gene repression (Figure 1); however, as discussed above, imprinted genes are major targets of H3K9me3. There is also evidence that $\mathrm{H} 3 \mathrm{~K} 9 \mathrm{me} 3$ is involved in repression of other genes, for example, nuclear receptor targets (Wissmann et al., 2007). Importantly, a lower H3K9 methylation state, $\mathrm{H} 3 \mathrm{~K} 9 \mathrm{me} 2$, might also have repressive functions. Differentiated cells carry large domains, up to several megabases long, with high levels of H3K9me2, and genes within these domains are repressed (Wen et al., 2009).

In mammals, the different H3K9 methylation states are mediated by several enzymes (Table 2). H3K9me2 is mainly controlled by G9a and the related G9alike protein (GLP), which function as heterodimers (Tachibana et al., 2005). Suv39h1 and Suv39h2 induce $\mathrm{H} 3 \mathrm{~K} 9 \mathrm{me} 3$ at heterochromatin. Little is known about the HMTases that are responsible for 'euchromatic' H3K9me3. The only good candidate for such an enzyme is Setdb1, which, as a recombinant enzyme, has poor activity. However, association with the auxiliary factor mAM confers $\mathrm{H} 3 \mathrm{~K} 9 \mathrm{me} 3$ activity to this enzyme (Wang et al., 2003). Setdb1 is an important functional constituent of the Kap1 corepressor complex that mainly uses $\mathrm{H} 3 \mathrm{~K} 9 \mathrm{me} 3$ as a means of gene repression (Sripathy et al., 2006). To what extent Setdb1 is really responsible for H3K9me3 in vivo remains to be tested.

Different histone methylation states are thought to confer distinct functions. For H3K9 methylation, it is still unclear whether di- or trimethyl states are functionally distinct. The best characterized binding protein, HP1 (Table 1), has affinity to both $\mathrm{H} 3 \mathrm{~K} 9 \mathrm{me} 2$ and $\mathrm{H} 3 \mathrm{~K} 9 \mathrm{me} 3$ in vitro (Lachner et al., 2001). H3K9 methylation seems to be crucial for HP1 recruitment and binding to heterochromatin, as Suv39h-mutant cells that lose H3K9me3 also lose HP1 from heterochromatin (Lachner et al., 2001). It is also very likely, however, that additional factors can stabilize the binding of HP1 at H3K9me2/3 targets. How silencing is then facilitated by $\mathrm{H} 3 \mathrm{~K} 9$ methylation is still unclear. The current model suggests that HP1 binding induces a higher grade of chromatin compaction, which would prevent access of transcription factors or RNA Pol II to DNA.

\section{Developmental functions of HMTases}

In the previous sections, we discussed functions of histone lysine methylation marks in gene activation and repression, but how important are these mechanisms for normal development? Over the past few years, knockout mice for several HMTases have been established and characterized. In the following sections, we will summarize these data and discuss the functional implications of histone lysine methylation for cell-type identity and regulation of developmental transitions.

\section{Gene activation by H3K4 methylation}

Activation of genes often correlates with $\mathrm{H} 3 \mathrm{~K} 4 \mathrm{me} 3$ at the promoter region. It is not really clear whether $\mathrm{H} 3 \mathrm{~K} 4 \mathrm{me} 3$ is a consequence of RNA Pol II recruitment or whether this modification represents a poised state for genes that can be easily activated. The major enzymes that induce 
H3K4 methylation states in mice are Mll1-5 (mixed lymphoid leukemia) family members, Setd1a/b enzymes and Ash11 (Table 2). Mll proteins are regarded as important regulators of development as homologous proteins in Drosophila (trithorax) positively regulate expression of homeotic genes. This function is conserved in mammals and disruption of individual Mll genes in mice leads to reduced expression of Hox genes and developmental defects, as will be outlined below.

Mll1 was the first Mll family member to be functionally analyzed in mice. Dependent on the knockout strategy, Mll1 disruption results in different phenotypes. Truncation of Mll1 in exon 3b or deletion of exons 9-11 both lead to embryonic lethality between E12.5 and E16.5 (Yu et al., 1995; Yagi et al., 1998). Even heterozygous Mll1 ${ }^{+/-}$knockout mice show defects in segment identity that are caused by reduced expression of distinct Hox genes (Hoxa-9 and Hoxc-7).

A very powerful model system to analyze development and differentiation is the hematopoietic system with well-defined stem cells, progenitor populations and differentiated cells. It is noteworthy that $\mathrm{Mll1}^{-/-}$ embryos fail to generate or expand hematopoietic stem cells during embryogenesis (Ernst et al., 2004), and, consistent with these data, conditional inactivation of Mll1 in adult mice also disrupts the hematopoietic stem cell compartment (Jude et al., 2007; McMahon et al., 2007). Although the mechanism is not clear, it seems plausible that impaired Hox gene regulation might contribute to these defects in the hematopoietic system (Lawrence et al., 2005).

To understand the function of Mll1-mediated $\mathrm{H} 3 \mathrm{~K} 4 \mathrm{me}$, another allele was generated that deletes the SET domain region (Terranova et al., 2006). In contrast to all other Mll1 knockout alleles, $\triangle$ SET mutants are fully viable and show only slight homeotic transformations. However, in $\triangle$ SET mutants, expression of distinct Hox genes is also reduced (Hoxd-4 and Hoxc-8), indicating that the methyltransferase activity of Mll1 is important for gene activation. On the other hand, the relatively mild phenotype of $\triangle$ SET and the only modest downregulation of Hox genes suggest compensatory mechanisms that allow a rather normal development of these mutants.

Mll1 deficiency does not impair overall H3K4 methylation as several other H3K4-specific methyltransferases exist in mice that can compensate for the loss of Mll1 (Table 2). Three other Mll family members have been disrupted in mice (Mll2, Mll3 and Mll5). These mutants show different phenotypes, suggesting different targets or functions. Mll2 ${ }^{-1-}$ mice are growth retarded and show embryonic lethality around E11.5 (Glaser et al., 2006). In mutant embryos and ES cell lines, a higher apoptosis rate might be caused by downregulation of the anti-apoptotic factor Bcl2 (Lubitz et al., 2007). In Mll2 ${ }^{-/-}$ES cells, very few genes are misregulated, suggesting that Mll2 has very few unique targets in this cell type (Glaser et al., 2009). One target gene, Magoh2, which is downregulated in Mll2 $2^{-1-}$ ES cells, loses $\mathrm{H} 3 \mathrm{~K} 4 \mathrm{me} 3$ at the promoter region. Interestingly, there is a concomitant increase in H3K27me3, indicating that chromatin modifications at Mll target genes are negotiated between antagonizing activities of the Mll group HMTases and Ezh enzymes.

Mll3 and Mll4 are present in complexes that share the PTIP (Pax transactivation domain-interacting protein) subunit, which is not present in Mll1 or Mll2 complexes (Cho et al., 2007). The difference in complex composition might also regulate targeting to distinct sets of genes. Mll3/4 have no apparent effect on Hox gene expression. Instead, they regulate $\mathrm{H} 3 \mathrm{~K} 4$ methylation at targets of the nuclear hormone receptors, retinoic acid receptor and peroxisome proliferator-activated receptor $\gamma$ (Lee et al., 2006, 2008a). Mll3-mutant mice are viable and do not show severe patterning defects; however, differentiation to distinct lineages, for example, adipocytes, is partially impaired, indicating an important function of Mll3 for normal development (Lee et al., 2008a).

Ml15 was regarded as inactive for a long time as no methyltransferase activity of the recombinant protein could be detected. A recent study has since shown that Mll5 is a histone H3K4-specific methyltransferase whose activity critically depends on GlcNacylation of Threonin 440 (Fujiki et al., 2009). Mll5 knockout mice are born at Mendelian ratios; only a few pups die during the first days postpartum. These data indicate that there are no severe developmental defects associated with loss of Mll5; however, closer inspection of the surviving mutants revealed that hematopoietic development is impaired and, in particular, the function of hematopoietic stem cells is reduced (Heuser et al., 2009; Madan et al., 2009; Zhang et al., 2009).

The enzymatic system for H3K4 methylation in mammals is highly complex. Mll proteins are a part of large complexes with common components and distinct interaction partners. Mll1 and Mll2 complexes share the common Menin subunit. Single Mll1 or Mll2 mutants impair H3K4 methylation at only a subset of Hox genes. Disruption of Menin has a much stronger effect and almost all H3K4 methylation is lost from Hox loci (Wang et al., 2009). Much less is known about targets of the other H3K4 HMTases. Although Mll3-5 induce only some H3K4 methylation outside of the Hox loci, Setd1a/ Setd1b HMTases have major roles in global H3K4 methylation (Wu et al., 2008). These enzymes are a part of multi-subunit complexes, most similar to the yeast COMPASS complex, and probably have a very general function in transcriptional activation. We expect that knockouts for these enzymes will generate severe defects, maybe even at the cellular level.

\section{Repression of developmental regulators by H3K27 methylation}

A classical model system for developmental gene regulation is the regulation of Hox gene expression. In Drosophila, the major players that determine transcriptional activity of distinct Hox genes are components of the activating trithorax and the repressive polycomb system, which are primarily recruited to specific DNA sequences (polycomb response elements). The founding member of the PcG family in Drosophila is polycomb, a chromo domain-containing protein whose targeting depends on H3K27me3 by E(z) (Cao et al., 2002). In mammals, many PcG components are conserved; however, the primary targeting mechanism is still unclear, as no polycomb response elements have been identified as yet.

In mice, there are two H3K27-specific HMTases, Ezh1 and Ezh2 (Table 2). Interestingly, their expression 
patterns differ as Ezh2 is predominantly expressed in undifferentiated/proliferating cells, whereas Ezh1 is more abundant on terminal differentiation (Margueron et al., 2008; Ezhkova et al., 2009).

H3K27 methylation correlates with gene repression and is enriched at repressed Hox genes and in female mammals at the inactive $X$ chromosome. Thus, deregulation of Ezh enzymes in mice is expected to generate strong phenotypes by affecting the gene activity of important developmental regulators. Indeed, Ezh2 knockout mice show early embryonic lethality around E8.5 (O'Carroll et al., 2001). Ezh2 knockout ES cells can be established and selectively lose H3K27me2 and H3K27me3 while maintaining H3K27me1. Interestingly, at some important developmental genes, H3K27me3 is preserved in Ezh2 ${ }^{-/-}$ES cells (Shen et al., 2008), indicating that Ezh1 and Ezh2 share partially redundant functions.

To analyze the function of H3K27me3 for developmental transitions, conditional Ezh2 knockout mice were established ( $\mathrm{Su}$ et al., 2003). During B cell development, Ezh2 is highly expressed in early progenitor populations (pro-B and pre-B cells), whereas Ezh1 is only expressed in late stages. Inactivation of Ezh2 in the hematopoietic lineage blocks the transition from pro-B to pre-B cells; however, later stages of B cell development are not impaired (Su et al., 2003). In this model system, transcriptional deregulation has not been investigated and the reason for the developmental block at the pro-B cell stage might be the improper processing of antigen receptor rearrangements.

Ezh2 deletion was also analyzed in skin development, in which basal layer progenitor stages can be distinguished from suprabasal cells that have initiated the program of terminal differentiation. Again, expression of Ezh2 is highest in the progenitor population and decreases with differentiation stage (Ezhkova et al., 2009). Deletion of Ezh2 in developing skin leads to dramatic loss of H3K27me3, resulting in accelerated epidermal differentiation and precocious acquisition of the epidermal barrier. Gene expression analysis of wild-type versus Ezh2-deleted epidermal precursor cells revealed that although H3K27me3 was almost lost in these cells, only approximately 90 genes were deregulated (mostly upregulated). Most of these genes are normally expressed in the final stages of epidermal development. The premature activation of the terminal differentiation program in the absence of Ezh2 suggests that transcriptional activators for epidermal differentiation are already present in the progenitor stages and that $H 3 \mathrm{~K} 27 \mathrm{me} 3$ blocks their access to target promoters (Ezhkova et al., 2009). Most other genes, which also lose H3K27me3 in the absence of Ezh2, are not activated, suggesting that they are repressed by different mechanisms or that appropriate transcriptional activators are not expressed in this tissue. The question as to how H3K27me3 can block the binding of transcription factors has not been addressed. The intriguing possibility that specific binders of H3K27me3, for example, Cbx2 in the context of the PRC1 complex, mediate compaction of the chromatin structure should be tested in future studies.

We think that H3K27me3 has a major role for developmental transitions (Figure 5). In pluripotent cells, developmental regulators are repressed by the bivalent modifications H3K27me3 and H3K4me3. After lineage decision, these genes are either active and carry $\mathrm{H} 3 \mathrm{~K} 4 \mathrm{me} 3$ or they are inactive and show enriched signals for H3K27me3. Apparently, in committed progenitor cells there are at least two categories of H3K27me3-repressed genes. One category is lineage-appropriate genes that need to be activated in later stages of differentiation. Full activation of these genes depends on removal of H3K27me3, probably by histone demethylases (Agger et al., 2007; Lan et al., 2007) that would then allow binding of transcriptional activators. Lineage-inappropriate genes, the second category, need to be stably repressed by H3K27me3 together with other mechanisms, such as different histone methylation marks or DNA methylation. Aberrant activation of lineage-inappropriate genes might as well be prevented by the lack of transcriptional activators. More detailed analyses are required to distinguish between these possibilities.

\section{Repression of repetitive elements and gene regulation by $\mathrm{H} 3 \mathrm{~K} 9$ methylation}

The first H3K9-specific methyltransferases that were disrupted in mice were the Suv39h1 and Suv39h2

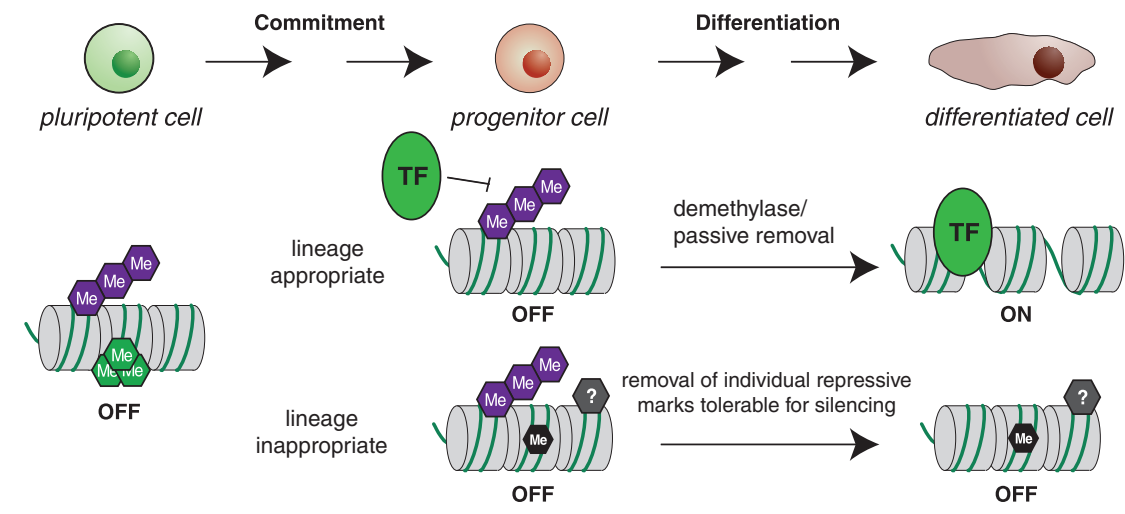

Figure 5 The role of H3K27me3-mediated gene silencing during developmental transitions. In pluripotent cells, developmental regulators are repressed and carry bivalent $\mathrm{H} 3 \mathrm{~K} 4 \mathrm{me} 3+\mathrm{H} 3 \mathrm{~K} 27 \mathrm{me} 3$ modifications. Bivalent marks are reduced in committed progenitor cells in which two categories of H3K27me3-repressed genes exist. Lineage-appropriate genes are activated during terminal differentiation, probably by the active removal of H3K27me3. In contrast, lineage-inappropriate genes are stably repressed by H3K27me3 and other mechanisms, such as different histone modifications and DNA methylation. 
enzymes (Peters et al., 2001). Single mutants do not show obvious defects, possibly due to compensatory effects. Surprisingly, even Suv39h double mutants are viable, although they show some prenatal lethality during embryogenesis. In Suv39h double-null cells, H3K9me3 is lost from heterochromatin; however, total H3K9me3 levels are only reduced by approximately 50\%. Suv39h mainly regulates repetitive regions, such as major satellite repeats and transposons (Martens et al., 2005), as no target genes of Suv39h enzymes could be identified as yet. Alterations in the chromatin structure across repetitive elements can have drastic effects on overall genome stability. It is noteworthy that Suv39h doublenull fibroblasts show increased chromosome segregation defects, indicating that centromere function is impaired. Genomic instability could also contribute to tumor development and sterility, which was observed in Suv39h-mutant mice (Peters et al., 2001). These findings show that H3K9me3 has important functions for genomic integrity by repression of mobile elements, thereby ensuring normal development and long-term survival.

Another H3K9-specific HMTase, Setdb1, has been suggested to induce $\mathrm{H} 3 \mathrm{~K} 9 \mathrm{me} 3$ for gene repression. Setdb1 knockout mice show a strong phenotype with peri-implantation lethality between days E3.5 and E5.5. The defects are so severe that not even embryonic stem cell lines could be established from null mutant blastocysts (Dodge et al., 2004), the reason for which is not understood. Setdb1-mediated H3K9me3 might have important roles in later developmental transitions by regulating targets of transcription factors (Yang et al., 2002) and nuclear hormone receptors (Takada et al., 2007). In a very elegant study, Takada et al. (2007) show that in mesenchymal cells of the bone marrow, noncanonical Wnt signaling induces phosphorylation of Setdb1, which leads to the formation of a corepressor complex with peroxisome proliferator-activated receptor- $\gamma$. Repression of peroxisome proliferator-activated receptor- $\gamma$ targets by $\mathrm{H} 3 \mathrm{~K} 9 \mathrm{me} 3$ drives differentiation of mesenchymal stem cells into the osteoblastic lineage. Catalytically inactive Setdb1 mutants could not ensure repression of peroxisome proliferator-activated receptor$\gamma$ targets, leading to differentiation of the mesenchymal cells into adipocytes. These findings show that H3K9me3-mediated gene repression is extremely important to establish transcriptional programs during lineage decisions. Conditional inactivation of Setdb1 in different tissues will surely reveal additional implications of this essential HMTase for normal development.

$\mathrm{H} 3 \mathrm{~K} 9 \mathrm{me} 2$ is a mainly euchromatic modification that is controlled by G9a and GLP HMTases (Table 2). G9a knockout mice show severe defects during embryogenesis, leading to developmental delay and lethality around day E9.5 (Tachibana et al., 2002). Unlike Suv39h1 and Suv39h2 that work redundantly to induce H3K9me3 at heterochromatin, heterodimer formation between G9a and GLP is essential to establish H3K9me2. Thus, GLP mutant embryos show defects that are almost identical to the G9a knockout, and double inactivation of G9a and GLP does not cause stronger phenotypes (Tachibana et al., 2005).

G9a-mutant ES cells show only little transcriptional deregulation and only one target gene, Mage-2a, has been shown as a direct target (Tachibana et al., 2002). Interestingly, G9a-mediated H3K9 methylation has im- portant functions during the differentiation of ES cells through the stable inactivation of approximately 120 genes, including the pluripotency genes Oct4 and Nanog (Feldman et al., 2006; Epsztejn-Litman et al., 2008). Stability of silencing is ensured through DNA methylation by Dnmt3a/b, which directly interacts with G9a (Epsztejn-Litman et al., 2008).

G9a mediates H3K9 methylation in another developmentally important context: genomic imprinting. In extraembryonic tissues, imprinting of the Kcnq1 domain is not dependent on DNA methylation, but the ICR shows high levels of $\mathrm{H} 3 \mathrm{~K} 9 \mathrm{me} 2$ and $\mathrm{H} 3 \mathrm{~K} 9 \mathrm{me} 3$. It is noteworthy that G9a mutants lose parental-specific imprinting of the Kcnq1 region selectively in the extraembryonic tissue through loss of $\mathrm{H} 3 \mathrm{~K} 9 \mathrm{me} 2$ and H3K9me3 (Wagschal et al., 2008). Although the average enrichment of H3K9 methylation states across silenced genes (Figure 1) has not suggested major roles for this modification in gene regulation, the abovementioned examples show that both $\mathrm{H} 3 \mathrm{~K} 9 \mathrm{me} 2$ and $\mathrm{H} 3 \mathrm{~K} 9 \mathrm{me} 3$ have important functions for gene silencing and for the regulation of developmental transitions.

\section{Concluding remarks}

The functional analysis of different HMTases in the context of knockout mouse models has revealed that histone lysine methylation has important roles in facilitating normal development; however, there are still many open questions. Knockout mice for only approximately $50 \%$ of mouse HMTases have been generated and analyzed (Table 2), and for many of these proteins we do not even know their enzymatic activity. Several HMTase mutants show early embryonic lethality with pleiotropic defects. A more detailed functional analysis in different tissues is required to better understand their functional implications in developmental processes. The paper by Ezhkova et al. (2009) is a very appropriate example for such an analysis.

How are different histone lysine methylation marks interpreted? Are different methylation states really functionally distinct? We only know binding proteins for a subset of positions and methylation states (Table 1). In vitro, most binders analyzed so far show only weak affinity to their targets, and the different methylation states cannot be clearly distinguished. Are there other mechanisms in vivo that could increase the affinity to their targets?

Epigenetic gene regulation has become a very complex field. In this review, we have only covered the functions of histone lysine methylation in transcriptional regulation; however, there is interplay and dependency between many different epigenetic mechanisms. Chromatin remodelers, for example, recognize histone modifications and can also mediate the exchange of histone variants (Konev et al., 2007). Non-coding RNAs are able to recruit histone-modifying activities that ultimately alter the transcriptional status of targets (Nagano et al., 2008). Histone modifications can be established in sequential pathways in which one modification recruits specific binders and these proteins, in turn, recruit other modifying activities (Schotta et al., 2004). The future challenge in epigenetic research will be to understand this complex network of regulatory mechanisms. 


\section{Conflict of interest}

The authors declare no conflict of interest.

\section{Acknowledgements}

We apologize to all authors whose work we could not cite because of space limitations. We are grateful to Antonia Jack for a critical reading of the paper. Research in the laboratory of G.S. was financed by the SFB-TR5 Chromatin, Center of Integrated Protein Science Munich and Friedrich Baur-Stiftung.

\section{References}

Agger K, Cloos PA, Christensen J, Pasini D, Rose S, Rappsilber J et al. (2007). UTX and JMJD3 are histone H3K27 demethylases involved in HOX gene regulation and development. Nature 449: 731-734.

Allfrey VG, Faulkner R, Mirsky AE (1964). Acetylation and methylation of histones and their possible role in the regulation of RNA synthesis. Proc Natl Acad Sci USA 51: 786-794.

Barski A, Cuddapah S, Cui K, Roh TY, Schones DE, Wang Z et al. (2007). High-resolution profiling of histone methylations in the human genome. Cell 129: 823-837.

Belotserkovskaya R, Reinberg D (2004). Facts about FACT and transcript elongation through chromatin. Curr Opin Genet Dev 14: 139-146.

Benetti R, Gonzalo S, Jaco I, Schotta G, Klatt P, Jenuwein Tet al. (2007). Suv4-20h deficiency results in telomere elongation and derepression of telomere recombination. J Cell Biol 178: 925-936.

Bernstein BE, Mikkelsen TS, Xie X, Kamal M, Huebert DJ, Cuff J et al. (2006a). A bivalent chromatin structure marks key developmental genes in embryonic stem cells. Cell 125: 315-326.

Bernstein E, Duncan EM, Masui O, Gil J, Heard E, Allis CD (2006b). Mouse polycomb proteins bind differentially to methylated histone $\mathrm{H} 3$ and RNA and are enriched in facultative heterochromatin. Mol Cell Biol 26: 2560-2569.

Botuyan MV, Lee J, Ward IM, Kim JE, Thompson JR, Chen J et al. (2006). Structural basis for the methylation state-specific recognition of histone $\mathrm{H} 4-\mathrm{K} 20$ by $53 \mathrm{BP} 1$ and $\mathrm{Crb} 2$ in DNA repair. Cell 127: 1361-1373.

Brown MA, Sims III RJ, Gottlieb PD, Tucker PW (2006). Identification and characterization of Smyd2: a split SET/ MYND domain-containing histone $\mathrm{H} 3$ lysine 36-specific methyltransferase that interacts with the Sin3 histone deacetylase complex. Mol Cancer 5: 26.

Cao R, Wang L, Wang H, Xia L, Erdjument-Bromage H, Tempst $P$ et al. (2002). Role of histone H3 lysine 27 methylation in Polycomb-group silencing. Science 298: 1039-1043.

Carrozza MJ, Li B, Florens L, Suganuma T, Swanson SK, Lee KK et al. (2005). Histone $\mathrm{H} 3$ methylation by Set2 directs deacetylation of coding regions by $\mathrm{Rpd} 3 \mathrm{~S}$ to suppress spurious intragenic transcription. Cell 123: 581-592.

Chamberlain SJ, Yee D, Magnuson T (2008). Polycomb repressive complex 2 is dispensable for maintenance of embryonic stem cell pluripotency. Stem Cells 26: 1496-1505.

Champagne KS, Saksouk N, Pena PV, Johnson K, Ullah M, Yang XJ et al. (2008). The crystal structure of the ING5 PHD finger in complex with an H3K4me3 histone peptide. Proteins $\mathbf{7 2}$ 1371-1376.

Cho YW, Hong T, Hong S, Guo H, Yu H, Kim D et al. (2007). PTIP associates with MLL3- and MLL4-containing histone H3 lysine 4 methyltransferase complex. J Biol Chem 282: 20395-20406.

Collins RE, Northrop JP, Horton JR, Lee DY, Zhang X, Stallcup MR et al. (2008). The ankyrin repeats of G9a and GLP histone methyltransferases are mono- and dimethyllysine binding modules. Nat Struct Mol Biol 15: 245-250.

Core LJ, Lis JT (2008). Transcription regulation through promoter-proximal pausing of RNA polymerase II. Science 319: 1791-1792.

Cui K, Zang C, Roh TY, Schones DE, Childs RW, Peng W et al. (2009). Chromatin signatures in multipotent human hematopoietic stem cells indicate the fate of bivalent genes during differentiation. Cell Stem Cell 4: 80-93.

Daujat S, Weiss T, Mohn F, Lange UC, Ziegler-Birling C, Zeissler $\mathrm{U}$ et al. (2009). H3K64 trimethylation marks heterochromatin and is dynamically remodeled during developmental reprogramming. Nat Struct Mol Biol 16: 777-781.

Dodge JE, Kang YK, Beppu H, Lei H, Li E (2004). Histone H3K9 methyltransferase ESET is essential for early development. Mol Cell Biol 24: 2478-2486.

Edmunds JW, Mahadevan LC, Clayton AL (2008). Dynamic histone $\mathrm{H} 3$ methylation during gene induction: $\mathrm{HYPB} /$ Setd2 mediates all H3K36 trimethylation. EMBO J 27: 406-420.

Epsztejn-Litman S, Feldman N, Abu-Remaileh M, Shufaro Y, Gerson A, Ueda J et al. (2008). De novo DNA methylation promoted by G9a prevents reprogramming of embryonically silenced genes. Nat Struct Mol Biol 15: 1176-1183.

Ernst P, Fisher JK, Avery W, Wade S, Foy D, Korsmeyer SJ (2004). Definitive hematopoiesis requires the mixed-lineage leukemia gene. Dev Cell 6: 437-443.

Eymery A, Callanan M, Vourc'h C (2009). The secret message of heterochromatin: new insights into the mechanisms and function of centromeric and pericentric repeat sequence transcription. Int J Dev Biol 53: 259-268.

Ezhkova E, Pasolli HA, Parker JS, Stokes N, Su IH, Hannon G et al. (2009). Ezh2 orchestrates gene expression for the stepwise differentiation of tissue-specific stem cells. Cell 136: 1122-1135.

Feldman N, Gerson A, Fang J, Li E, Zhang Y, Shinkai Y et al. (2006). G9a-mediated irreversible epigenetic inactivation of Oct-3/4 during early embryogenesis. Nat Cell Biol 8: 188-194.

Feng Q, Wang $\mathrm{H}, \mathrm{Ng} \mathrm{HH}$, Erdjument-Bromage $\mathrm{H}$, Tempst $\mathrm{P}$, Struhl K et al. (2002). Methylation of H3-lysine 79 is mediated by a new family of HMTases without a SET domain. Curr Biol 12: $1052-1058$

Fischle W, Franz H, Jacobs SA, Allis CD, Khorasanizadeh S (2008). Specificity of the chromodomain Y chromosome family of chromodomains for lysine-methylated ARK(S/T) motifs. J Biol Chem 283: 19626-19635.

Flanagan JF, Mi LZ, Chruszcz M, Cymborowski M, Clines KL, Kim Y et al. (2005). Double chromodomains cooperate to recognize the methylated histone H3 tail. Nature 438: 1181-1185.

Fournier C, Goto Y, Ballestar E, Delaval K, Hever AM, Esteller M et al. (2002). Allele-specific histone lysine methylation marks regulatory regions at imprinted mouse genes. EMBOJ 21: 6560-6570.

Fuda NJ, Ardehali MB, Lis JT (2009). Defining mechanisms that regulate RNA polymerase II transcription in vivo. Nature 461: 186-192.

Fujiki R, Chikanishi T, Hashiba W, Ito H, Takada I, Roeder RG et al. (2009). GlcNAcylation of a histone methyltransferase in retinoic-acid-induced granulopoiesis. Nature 459: 455-459.

Glaser S, Lubitz S, Loveland KL, Ohbo K, Robb L, Schwenk F et al. (2009). The histone 3 lysine 4 methyltransferase, Mll2, is only required briefly in development and spermatogenesis. Epigenetics Chromatin 2: 5.

Glaser S, Schaft J, Lubitz S, Vintersten K, van der Hoeven F, Tufteland KR et al. (2006). Multiple epigenetic maintenance factors implicated by the loss of Mll2 in mouse development. Development 133: 1423-1432.

Gonzalo S, Garcia-Cao M, Fraga MF, Schotta G, Peters AH, Cotter SE et al. (2005). Role of the RB1 family in stabilizing histone methylation at constitutive heterochromatin. Nat Cell Biol 7: 420-428. 
Goo YH, Sohn YC, Kim DH, Kim SW, Kang MJ, Jung DJ et al. (2003). Activating signal cointegrator 2 belongs to a novel steady-state complex that contains a subset of trithorax group proteins. Mol Cell Biol 23: 140-149.

Gottlieb PD, Pierce SA, Sims RJ, Yamagishi H, Weihe EK, Harriss JV et al. (2002). Bop encodes a muscle-restricted protein containing MYND and SET domains and is essential for cardiac differentiation and morphogenesis. Nat Genet 31: $25-32$.

Gregory GD, Vakoc CR, Rozovskaia T, Zheng X, Patel S, Nakamura T et al. (2007). Mammalian ASH1L is a histone methyltransferase that occupies the transcribed region of active genes. Mol Cell Biol 27: 8466-8479.

Grewal SI, Jia S (2007). Heterochromatin revisited. Nat Rev Genet 8: 35-46.

Hamamoto R, Furukawa Y, Morita M, Iimura Y, Silva FP, Li M et al. (2004). SMYD3 encodes a histone methyltransferase involved in the proliferation of cancer cells. Nat Cell Biol 6: 731-740.

Hayashi K, Yoshida K, Matsui Y (2005). A histone H3 methyltransferase controls epigenetic events required for meiotic prophase. Nature 438: 374-378.

Henckel A, Nakabayashi K, Sanz LA, Feil R, Hata K, Arnaud P (2009). Histone methylation is mechanistically linked to DNA methylation at imprinting control regions in mammals. Hum Mol Genet 18: 3375-3383.

Heuser M, Yap DB, Leung $M$, de Algara TR, Tafech A, McKinney $S$ et al. (2009). Loss of MLL5 results in pleiotropic hematopoietic defects, reduced neutrophil immune function, and extreme sensitivity to DNA demethylation. Blood 113: 1432-1443.

Hoyt PR, Bartholomew C, Davis AJ, Yutzey K, Gamer LW, Potter SS et al. (1997). The Evi1 proto-oncogene is required at midgestation for neural, heart, and paraxial mesenchyme development. Mech Dev 65: 55-70.

Hung T, Binda O, Champagne KS, Kuo AJ, Johnson K, Chang HY et al. (2009). ING4 mediates crosstalk between histone H3 $\mathrm{K} 4$ trimethylation and $\mathrm{H} 3$ acetylation to attenuate cellular transformation. Mol Cell 33: 248-256.

Huyen Y, Zgheib O, Ditullio Jr RA, Gorgoulis VG, Zacharatos P, Petty TJ et al. (2004). Methylated lysine 79 of histone H3 targets 53BP1 to DNA double-strand breaks. Nature 432: 406-411.

Jacobson RH, Ladurner AG, King DS, Tjian R (2000). Structure and function of a human TAFII250 double bromodomain module. Science 288: 1422-1425.

Jamai A, Puglisi A, Strubin M (2009). Histone chaperone spt16 promotes redeposition of the original h3-h4 histones evicted by elongating RNA polymerase. Mol Cell 35: 377-383.

Jones B, Su H, Bhat A, Lei H, Bajko J, Hevi S et al. (2008). The histone H3K79 methyltransferase Dot1L is essential for mammalian development and heterochromatin structure. PLoS Genet 4: e1000190.

Jude CD, Climer L, Xu D, Artinger E, Fisher JK, Ernst P (2007). Unique and independent roles for MLL in adult hematopoietic stem cells and progenitors. Cell Stem Cell 1: 324-337.

Kim KC, Geng L, Huang S (2003). Inactivation of a histone methyltransferase by mutations in human cancers. Cancer Res 63: 7619-7623.

Kim T, Buratowski S (2009). Dimethylation of H3K4 by Set1 recruits the Set3 histone deacetylase complex to $5^{\prime}$ transcribed regions. Cell 137: 259-272.

Kolasinska-Zwierz P, Down T, Latorre I, Liu T, Liu XS, Ahringer J (2009). Differential chromatin marking of introns and expressed exons by H3K36me3. Nat Genet 41: 376-381.

Konev AY, Tribus M, Park SY, Podhraski V, Lim CY, Emelyanov $\mathrm{AV}$ et al. (2007). CHD1 motor protein is required for deposition of histone variant $\mathrm{H} 3.3$ into chromatin in vivo. Science 317: 1087-1090.
$\mathrm{Ku} \mathrm{M}$, Koche RP, Rheinbay E, Mendenhall EM, Endoh M, Mikkelsen TS et al. (2008). Genomewide analysis of PRC1 and PRC2 occupancy identifies two classes of bivalent domains. PLoS Genet 4: e1000242.

Kurash JK, Lei H, Shen Q, Marston WL, Granda BW, Fan H et al. (2008). Methylation of p53 by Set7/9 mediates p53 acetylation and activity in vivo. Mol Cell 29: 392-400.

Lachner M, O'Carroll D, Rea S, Mechtler K, Jenuwein T (2001). Methylation of histone H3 lysine 9 creates a binding site for HP1 proteins. Nature 410: 116-120.

Lan F, Bayliss PE, Rinn JL, Whetstine JR, Wang JK, Chen S et al. (2007). A histone H3 lysine 27 demethylase regulates animal posterior development. Nature 449: 689-694.

Lawrence HJ, Christensen J, Fong S, Hu YL, Weissman I, Sauvageau G et al. (2005). Loss of expression of the Hoxa-9 homeobox gene impairs the proliferation and repopulating ability of hematopoietic stem cells. Blood 106: 3988-3994.

Lee BM, Mahadevan LC (2009). Stability of histone modifications across mammalian genomes: implications for 'epigenetic' marking. I Cell Biochem 108: 22-34.

Lee J, Saha PK, Yang QH, Lee S, Park JY, Suh Y et al. (2008a). Targeted inactivation of MLL3 histone H3-Lys-4 methyltransferase activity in the mouse reveals vital roles for MLL3 in adipogenesis. Proc Natl Acad Sci USA 105: 19229-19234.

Lee J, Thompson JR, Botuyan MV, Mer G (2008b). Distinct binding modes specify the recognition of methylated histones H3K4 and H4K20 by JMJD2A-tudor. Nat Struct Mol Biol 15: 109-111.

Lee JH, Tate CM, You JS, Skalnik DG (2007). Identification and characterization of the human Set1B histone H3-Lys4 methyltransferase complex. J Biol Chem 282: 13419-13428.

Lee S, Lee DK, Dou Y, Lee J, Lee B, Kwak E et al. (2006). Coactivator as a target gene specificity determinant for histone H3 lysine 4 methyltransferases. Proc Natl Acad Sci USA 103: 15392-15397.

Lee SH, Oshige M, Durant ST, Rasila KK, Williamson EA, Ramsey $\mathrm{H}$ et al. (2005). The SET domain protein Metnase mediates foreign DNA integration and links integration to nonhomologous end-joining repair. Proc Natl Acad Sci USA 102: $18075-18080$.

Leeb M, Pasini D, Novatchkova M, Jaritz M, Helin K, Wutz A (2010). Polycomb complexes act redundantly to repress genomic repeats and genes. Genes Dev 24: 265-276.

Lewis A, Mitsuya K, Umlauf D, Smith P, Dean W, Walter J et al. (2004). Imprinting on distal chromosome 7 in the placenta involves repressive histone methylation independent of DNA methylation. Nat Genet 36: 1291-1295.

Liu H, Westergard TD, Hsieh JJ (2009). MLL5 governs hematopoiesis: a step closer. Blood 113: 1395-1396.

Loyola A, Tagami H, Bonaldi T, Roche D, Quivy JP, Imhof A et al. (2009). The HP1alpha-CAF1-SetDB1-containing complex provides H3K9me1 for Suv39-mediated K9me3 in pericentric heterochromatin. EMBO Rep 10: 769-775.

Lubitz S, Glaser S, Schaft J, Stewart AF, Anastassiadis K (2007). Increased apoptosis and skewed differentiation in mouse embryonic stem cells lacking the histone methyltransferase Mll2. Mol Biol Cell 18: 2356-2366.

Madan V, Madan B, Brykczynska U, Zilbermann F, Hogeveen $\mathrm{K}$, Dohner $\mathrm{K}$ et al. (2009). Impaired function of primitive hematopoietic cells in mice lacking the Mixed-LineageLeukemia homolog MLL5. Blood 113: 1444-1454.

Margueron R, Justin N, Ohno K, Sharpe ML, Son J, Drury III WJ et al. (2009). Role of the polycomb protein EED in the propagation of repressive histone marks. Nature 461: 762-767.

Margueron R, Li G, Sarma K, Blais A, Zavadil J, Woodcock CL et al. (2008). Ezh1 and Ezh2 maintain repressive chromatin through different mechanisms. Mol Cell 32: 503-518.

Martens JH, O'Sullivan RJ, Braunschweig U, Opravil S, Radolf $\mathrm{M}$, Steinlein $\mathrm{P}$ et al. (2005). The profile of repeat-associated 
histone lysine methylation states in the mouse epigenome. EMBOJ 24: 800-812.

Matthews AG, Kuo AJ, Ramon-Maiques S, Han S, Champagne KS, Ivanov D et al. (2007). RAG2 PHD finger couples histone H3 lysine 4 trimethylation with V(D)J recombination. Nature 450: $1106-1110$.

McMahon KA, Hiew SY, Hadjur S, Veiga-Fernandes $H$, Menzel U, Price AJ et al. (2007). Mll has a critical role in fetal and adult hematopoietic stem cell self-renewal. Cell Stem Cell 1: 338-345.

Mikkelsen TS, Ku M, Jaffe DB, Issac B, Lieberman E, Giannoukos G et al. (2007). Genome-wide maps of chromatin state in pluripotent and lineage-committed cells. Nature 448: 553-560.

Milne TA, Briggs SD, Brock HW, Martin ME, Gibbs D, Allis CD et al. (2002). MLL targets SET domain methyltransferase activity to Hox gene promoters. Mol Cell 10: 1107-1117.

Milne TA, Dou Y, Martin ME, Brock HW, Roeder RG, Hess JL (2005). MLL associates specifically with a subset of transcriptionally active target genes. Proc Natl Acad Sci USA 102: 14765-14770.

Nagano T, Mitchell JA, Sanz LA, Pauler FM, Ferguson-Smith AC, Feil R et al. (2008). The Air noncoding RNA epigenetically silences transcription by targeting G9a to chromatin. Science 322: 1717-1720.

Nimura K, Ura K, Shiratori H, Ikawa M, Okabe M, Schwartz RJ et al. (2009). A histone H3 lysine 36 trimethyltransferase links Nkx2-5 to Wolf-Hirschhorn syndrome. Nature 460: 287-291.

Nishioka K, Chuikov S, Sarma K, Erdjument-Bromage H, Allis CD, Tempst P et al. (2002). Set9, a novel histone H3 methyltransferase that facilitates transcription by precluding histone tail modifications required for heterochromatin formation. Genes Dev 16: 479-489.

O'Carroll D, Erhardt S, Pagani M, Barton SC, Surani MA, Jenuwein $\mathrm{T}$ (2001). The polycomb-group gene Ezh2 is required for early mouse development. Mol Cell Biol 21: 4330-4336.

Oda H, Okamoto I, Murphy N, Chu J, Price SM, Shen MM et al. (2009). Monomethylation of histone H4-lysine 20 is involved in chromosome structure and stability and is essential for mouse development. Mol Cell Biol 29: 2278-2295.

Ohinata Y, Payer B, O'Carroll D, Ancelin K, Ono Y, Sano M et al. (2005). Blimp1 is a critical determinant of the germ cell lineage in mice. Nature 436: 207-213.

Pan G, Tian S, Nie J, Yang C, Ruotti V, Wei H et al. (2007). Wholegenome analysis of histone $\mathrm{H} 3$ lysine 4 and lysine 27 methylation in human embryonic stem cells. Cell Stem Cell 1: 299-312.

Pannetier M, Julien E, Schotta G, Tardat M, Sardet C, Jenuwein T et al. (2008). PR-SET7 and SUV4-20H regulate H4 lysine-20 methylation at imprinting control regions in the mouse. EMBO Rep 9: 998-1005.

Pauler FM, Sloane MA, Huang R, Regha K, Koerner MV, Tamir I et al. (2009). H3K27me3 forms BLOCs over silent genes and intergenic regions and specifies a histone banding pattern on a mouse autosomal chromosome. Genome Res 19: 221-233.

Pavri R, Zhu B, Li G, Trojer P, Mandal S, Shilatifard A et al. (2006). Histone H2B monoubiquitination functions cooperatively with FACT to regulate elongation by RNA polymerase II. Cell 125: 703-717.

Peters AH, O'Carroll D, Scherthan H, Mechtler K, Sauer S, Schofer C et al. (2001). Loss of the Suv39h histone methyltransferases impairs mammalian heterochromatin and genome stability. Cell 107: 323-337.

Rayasam GV, Wendling O, Angrand PO, Mark M, Niederreither $\mathrm{K}$, Song L et al. (2003). NSD1 is essential for early postimplantation development and has a catalytically active SET domain. EMBOJ 22: 3153-3163.
Rea S, Eisenhaber F, O'Carroll D, Strahl BD, Sun ZW, Schmid M et al. (2000). Regulation of chromatin structure by site-specific histone H3 methyltransferases. Nature 406: 593-599.

Regha K, Sloane MA, Huang R, Pauler FM, Warczok KE, Melikant B et al. (2007). Active and repressive chromatin are interspersed without spreading in an imprinted gene cluster in the mammalian genome. Mol Cell 27: 353-366.

Rinn JL, Kertesz M, Wang JK, Squazzo SL, Xu X, Brugmann SA et al. (2007). Functional demarcation of active and silent chromatin domains in human HOX loci by noncoding RNAs. Cell 129: 1311-1323.

Schoeftner S, Blasco MA (2008). Developmentally regulated transcription of mammalian telomeres by DNA-dependent RNA polymerase II. Nat Cell Biol 10: 228-236.

Schoeftner S, Sengupta AK, Kubicek S, Mechtler K, Spahn L, Koseki $\mathrm{H}$ et al. (2006). Recruitment of PRC1 function at the initiation of $X$ inactivation independent of PRC2 and silencing. EMBOJ 25: 3110-3122.

Schotta G, Lachner M, Sarma K, Ebert A, Sengupta R, Reuter G et al. (2004). A silencing pathway to induce H3-K9 and H4K20 trimethylation at constitutive heterochromatin. Genes Dev 18: 1251-1262.

Schotta G, Sengupta R, Kubicek S, Malin S, Kauer M, Callen E et al. (2008). A chromatin-wide transition to H4K20 monomethylation impairs genome integrity and programmed DNA rearrangements in the mouse. Genes Dev 22: 2048-2061.

Shen X, Liu Y, Hsu YJ, Fujiwara Y, Kim J, Mao X et al. (2008). EZH1 mediates methylation on histone $\mathrm{H} 3$ lysine 27 and complements EZH2 in maintaining stem cell identity and executing pluripotency. Mol Cell 32: 491-502.

Shi X, Hong T, Walter KL, Ewalt M, Michishita E, Hung T et al. (2006). ING2 PHD domain links histone H3 lysine 4 methylation to active gene repression. Nature 442: 96-99.

Spies N, Nielsen CB, Padgett RA, Burge CB (2009). Biased chromatin signatures around polyadenylation sites and exons. Mol Cell 36: 245-254.

Sripathy SP, Stevens J, Schultz DC (2006). The KAP1 corepressor functions to coordinate the assembly of de novo HP1demarcated microenvironments of heterochromatin required for KRAB zinc finger protein-mediated transcriptional repression. Mol Cell Biol 26: 8623-8638.

Steele-Perkins G, Fang W, Yang XH, Van Gele M, Carling T, Gu J et al. (2001). Tumor formation and inactivation of RIZ1, an $\mathrm{Rb}$-binding member of a nuclear protein-methyltransferase superfamily. Genes Dev 15: 2250-2262.

Strahl BD, Ohba R, Cook RG, Allis CD (1999). Methylation of histone $\mathrm{H} 3$ at lysine 4 is highly conserved and correlates with transcriptionally active nuclei in Tetrahymena. Proc Natl Acad Sci USA 96: 14967-14972.

Su IH, Basavaraj A, Krutchinsky AN, Hobert O, Ullrich A, Chait BT et al. (2003). Ezh2 controls B cell development through histone $\mathrm{H} 3$ methylation and Igh rearrangement. Nat Immunol 4: $124-131$.

Sun XJ, Wei J, Wu XY, Hu M, Wang L, Wang HH et al. (2005). Identification and characterization of a novel human histone H3 lysine 36-specific methyltransferase. J Biol Chem 280: 35261-35271.

Sun Y, Jiang X, Xu Y, Ayrapetov MK, Moreau LA, Whetstine JR et al. (2009). Histone H3 methylation links DNA damage detection to activation of the tumour suppressor Tip60. Nat Cell Biol 11: 1376-1382.

Tachibana M, Matsumura Y, Fukuda M, Kimura H, Shinkai Y (2008). G9a/GLP complexes independently mediate H3K9 and DNA methylation to silence transcription. EMBOJ 27: 2681-2690.

Tachibana M, Sugimoto K, Nozaki M, Ueda J, Ohta T, Ohki M et al. (2002). G9a histone methyltransferase plays a dominant role in euchromatic histone $\mathrm{H} 3$ lysine 9 methylation and is essential for early embryogenesis. Genes Dev 16: 1779-1791.

Tachibana M, Ueda J, Fukuda M, Takeda N, Ohta T, Iwanari H et al. (2005). Histone methyltransferases G9a and GLP form 
heteromeric complexes and are both crucial for methylation of euchromatin at H3-K9. Genes Dev 19: 815-826.

Takada I, Mihara M, Suzawa M, Ohtake F, Kobayashi S, Igarashi $\mathrm{M}$ et al. (2007). A histone lysine methyltransferase activated by non-canonical Wnt signalling suppresses PPAR-gamma transactivation. Nat Cell Biol 9: 1273-1285.

Tan X, Rotllant J, Li H, De Deyne P, Du SJ (2006). SmyD1, a histone methyltransferase, is required for myofibril organization and muscle contraction in zebrafish embryos. Proc Natl Acad Sci USA 103: 2713-2718.

Taverna SD, Ilin S, Rogers RS, Tanny JC, Lavender H, Li H et al. (2006). Yng1 PHD finger binding to $\mathrm{H} 3$ trimethylated at $\mathrm{K} 4$ promotes NuA3 HAT activity at K14 of $\mathrm{H} 3$ and transcription at a subset of targeted ORFs. Mol Cell 24: 785-796.

Terranova R, Agherbi H, Boned A, Meresse S, Djabali M (2006). Histone and DNA methylation defects at Hox genes in mice expressing a SET domain-truncated form of Mll. Proc Natl Acad Sci USA 103: 6629-6634.

Trojer P, Li G, Sims III RJ, Vaquero A, Kalakonda N, Boccuni P et al. (2007). L3MBTL1, a histone-methylation-dependent chromatin lock. Cell 129: 915-928.

Umlauf D, Goto Y, Cao R, Cerqueira F, Wagschal A, Zhang Y et al. (2004). Imprinting along the Kcnq1 domain on mouse chromosome 7 involves repressive histone methylation and recruitment of Polycomb group complexes. Nat Genet 36: 1296-1300.

Vermeulen M, Mulder KW, Denissov S, Pijnappel WW, van Schaik FM, Varier RA et al. (2007). Selective anchoring of TFIID to nucleosomes by trimethylation of histone $\mathrm{H} 3$ lysine 4. Cell 131: 58-69.

Vire E, Brenner C, Deplus R, Blanchon L, Fraga M, Didelot C et al. (2006). The Polycomb group protein EZH2 directly controls DNA methylation. Nature 439: 871-874.

Wagschal A, Sutherland HG, Woodfine K, Henckel A, Chebli K, Schulz R et al. (2008). G9a histone methyltransferase contributes to imprinting in the mouse placenta. Mol Cell Biol 28: 1104-1113.

Wang H, An W, Cao R, Xia L, Erdjument-Bromage H, Chatton B et al. (2003). mAM facilitates conversion by ESET of dimethyl to trimethyl lysine 9 of histone $\mathrm{H} 3$ to cause transcriptional repression. Mol Cell 12: 475-487.

Wang H, Cao R, Xia L, Erdjument-Bromage H, Borchers C, Tempst $P$ et al. (2001). Purification and functional characterization of a histone H3-lysine 4-specific methyltransferase. Mol Cell 8: 1207-1217.

Wang H, Wang L, Erdjument-Bromage H, Vidal M, Tempst P, Jones RS et al. (2004). Role of histone H2A ubiquitination in Polycomb silencing. Nature 431: 873-878.

Wang P, Lin C, Smith ER, Guo H, Sanderson BW, Wu M et al. (2009). Global analysis of H3K4 methylation defines MLL family member targets and points to a role for MLL1mediated H3K4 methylation in the regulation of transcriptional initiation by RNA polymerase II. Mol Cell Biol 29: 6074-6085.
Wen B, Wu H, Shinkai Y, Irizarry RA, Feinberg AP (2009). Large histone H3 lysine 9 dimethylated chromatin blocks distinguish differentiated from embryonic stem cells. Nat Genet 41: 246-250.

Wissmann M, Yin N, Muller JM, Greschik H, Fodor BD, Jenuwein $\mathrm{T}$ et al. (2007). Cooperative demethylation by JMJD2C and LSD1 promotes androgen receptor-dependent gene expression. Nat Cell Biol 9: 347-353.

Wu M, Wang PF, Lee JS, Martin-Brown S, Florens L, Washburn $\mathrm{M}$ et al. (2008). Molecular regulation of H3K4 trimethylation by Wdr82, a component of human Set1/COMPASS. Mol Cell Biol 28: 7337-7344.

Wysocka J, Myers MP, Laherty CD, Eisenman RN, Herr W (2003). Human Sin3 deacetylase and trithorax-related Set1/ Ash2 histone H3-K4 methyltransferase are tethered together selectively by the cell-proliferation factor HCF-1. Genes Dev 17: 896-911.

Wysocka J, Swigut T, Xiao H, Milne TA, Kwon SY, Landry J et al. (2006). A PHD finger of NURF couples histone H3 lysine 4 trimethylation with chromatin remodelling. Nature 442: 86-90.

Yagi H, Deguchi K, Aono A, Tani Y, Kishimoto T, Komori T (1998). Growth disturbance in fetal liver hematopoiesis of Mll-mutant mice. Blood 92: 108-117.

Yamaji M, Seki Y, Kurimoto K, Yabuta Y, Yuasa M, Shigeta M et al. (2008). Critical function of Prdm14 for the establishment of the germ cell lineage in mice. Nat Genet 40: 1016-1022.

Yang L, Xia L, Wu DY, Wang H, Chansky HA, Schubach WH et al. (2002). Molecular cloning of ESET, a novel histone H3specific methyltransferase that interacts with ERG transcription factor. Oncogene 21: 148-152.

Yochum GS, Ayer DE (2002). Role for the mortality factors MORF4, MRGX, and MRG15 in transcriptional repression via associations with Pf1, mSin3A, and Transducin-Like Enhancer of Split. Mol Cell Biol 22: 7868-7876.

Yoh SM, Lucas JS, Jones KA (2008). The Iws1:Spt6:CTD complex controls cotranscriptional mRNA biosynthesis and HYPB/ Setd2-mediated histone H3K36 methylation. Genes Dev 22: 3422-3434.

Yu BD, Hess JL, Horning SE, Brown GA, Korsmeyer SJ (1995). Altered Hox expression and segmental identity in Mllmutant mice. Nature 378: 505-508.

Zhang P, Du J, Sun B, Dong X, Xu G, Zhou J et al. (2006). Structure of human MRG15 chromo domain and its binding to Lys36-methylated histone H3. Nucleic Acids Res 34: 6621-6628.

Zhang Y, Wong J, Klinger M, Tran MT, Shannon KM, Killeen N (2009). MLL5 contributes to hematopoietic stem cell fitness and homeostasis. Blood 113: 1455-1463.

Zhou W, Zhu P, Wang J, Pascual G, Ohgi KA, Lozach J et al. (2008). Histone H2A monoubiquitination represses transcription by inhibiting RNA polymerase II transcriptional elongation. Mol Cell 29: 69-80. 